\title{
Japan's rejection of international norms against whaling
}

\author{
Riswanda Imawan ", Adde Marup Wirasenjaya, Muhammad Yafi Zhafran \\ International Program of International Relations, Faculty of Social and Political Sciences, Universitas \\ Muhammadiyah Yogyakarta, Indonesia, 55183
}

\begin{abstract}
This research is intended to explain the reasons for Japan's rejection of the anti-whaling norms. To investigate this, a qualitative approach was used with document-based data methods, both primary and secondary. Japan is one of the industrialized countries that have stopped hunting for commercial breaks because of the moratorium in 1982. This moratorium is a form of development of the anti-whaling norm. This research found that Japan is a country that chooses not to this norm with several reasons that state as a strong background for not including and not accepting the norm. This is evidenced by the continuing Japanese whaling through the scientific whaling program. If Japan stops this norm, so all Japanese whaling practices will also stop. The Japanese decision was the result of consideration in understanding norms through a better social context by Japan itself and Japanese society in general who could state in the concept of legitimacy of international norms. This decision was taken from Japan to decide to withdraw from the International Whaling Commission (IWC) in December 2018 which is also Japan's behavior after understanding this social context.
\end{abstract}

\section{Introduction}

The issue of animal welfare has become an issue that has begun to be widely discussed in international forums. Among them were discussed in the Convention on International Trade in Endaged Species of Wild Flora and Fauna (CITES) and the United Nations Conference on the Human Environment (UNCHE) in 1972. Whale hunting has various problems including the issue of research-based natural resources (scientific), animal welfare, to cultural issues [1]. The development of this anti-whaling norm has a long history, besides Japan, Norway and Iceland which still support whaling, other major countries that have also been involved in the commercial whaling industry are the United States, the Netherlands, and Russia, and the United Kingdom. Commercial whaling developed because almost all parts of the whale's body can be used as a layer of fat that can be converted into whale oil. Advances in technology have made commercial whaling grow rapidly, with whale hunting becoming easier and the range of the area covered is wider. The increasing demand for whale products became the impetus for the holding of the first multilateral agreement in

* Corresponding author: riswanda.i.isip17@mail.umy.ac.id 
1931, namely the International Convention for the Regulations of whaling (ICRW) which was intended to protect whales from the demand for whale oil so that the development of the whaling industry was expected to remain in accordance with the law. The agreement applies to all parts of the sea, but later the agreement failed due to weak enforcement [2].

In 1946, ICRW was held again in Washington DC, United States, this convention was considered to bring significant changes from the first convention in 1931. In the convention an institution or regime was formed as a decision maker, namely the International Whaling Commission (IWC). At its peak in 1982, the IWC experienced a shift in position from which previously only provided restrictions on whaling with the principle of sustainability into a strict prohibition through the 1982 moratorium. The reasons for the shift in the IWC's position were, first, the changing orientation of member countries' goals in the 1970s, such as the increasing number of members who refused to hunt whale. Second, the massive campaign carried out by anti-whaling groups that influenced the decision-making process at the IWC. Third, the succession to the formation of a coalition of anti-whaling groups at the IWC, this coalition is considered capable of controlling decision-making at the IWC.

One of the countries that conduct whaling as well as join the IWC is Norway, Iceland and especially Japan, which will be the focus of this research. Japan joined the IWC on 24 April 1951, citing common goals. Another reason is that the Japanese people experienced a hunger crisis after World War II, joining the IWC was also used to restore Japan's reputation internationally and to show the international community that Japan can also be a trusted partner that meets international standards.

In 1982, the IWC imposed a moratorium on commercial whaling which was booming that year, the moratorium was initiated at the Conference on Human Environment in Stockholm by the United Nations in 1972. Japan, which is the country that practices the largest commercial whaling, protested strongly against this moratorium. In 1985 to early 1987, Japan declared its withdrawal from the IWC because it refused to apply this moratorium. The imposition of this moratorium is a development of an anti-whaling norm that is popular and supported internationally. The formation of this norm not only gave birth to anti-whaling groups but also pro-whaling groups who also wanted to preserve whaling for various purposes. Australia, Germany, France, the United States and New Zealand are promoters of anti-whaling norms. Meanwhile, countries or groups that consider the moratorium unprofitable and protested by pro-whaling countries such as Norway, Iceland and especially Japan.

Before this moratorium was enforced, Japan's whaling industry area covered Antarctica to the waters of South Oceania and even entered the United States Exclusive Economic Zone, with the moratorium the Japanese whaling industry area automatically experienced a shrinking area and reduced number of hunted, and also decreased meat consumption. whales drastically and only reached tens of thousands of tons per year [3]. Whale hunting gave birth to a community in Japanese society, it was motivated by a life that intersects and is directly integrated with whales. These communities occupy several coastal areas in Japan which are also known as whaling towns, including Abashiri in Hokkaido, Ayukawa in Miyagi, Taiji in Wakayama, and Wada in Chiba.

In the 1990s Japan along with two other pro-whaling alliances Norway and Iceland urged the IWC to phase out the moratorium on commercial whaling. Japan only rejoined the IWC in 1987 and found an opportunity to continue its whaling by joining the scientific committee, which is in charge of conducting scientific research and publication of results, statistics, and reports on whales, this is in accordance with Article IV of the International Convention for the Regulation of Whaling (ICRW) [4]. The biggest reason for Japan to do scientific whaling is because the IWC's decision to impose a moratorium is not scientifically based, so Japan, Norway and Iceland believe that some whale populations such as the minke species are still safe to hunt [5]. However, in fact Japan's scientific 
whaling is considered a pretext for Japan to continue their commercial whaling even though the method used is scientifically coupled with the sale of whale meat.

The issue of whaling is also a big obstacle for Japan, especially in foreign relations, the article is that many anti-whaling countries which incidentally are allies of Japan, on the other hand this issue has developed into an international norm and its position is getting stronger because many countries have adopted and promoted it, and massive campaigns carried out by international environmental groups and animal lovers. Japan's attitude has not changed, by not adopting anti-whaling norms even in the 1982 moratorium, Japan has also been repeatedly pressured by its biggest ally, the United States. It is explained in a book Institutions of the Earth that Japan accepted the moratorium because of pressure and threats from the United States through its economic sanctions. The main reason why the US has given so many roles is because the IWC as an international regime lacks the power to pressure Japan to adopt this anti-whaling norm and this is done because of the US role as the whaling commission's police man. The reason for the large number of parties protesting was because Japan used scientific whaling as their pretext to continue the practice of commercial whaling. Many protests also come from environmental Non-Government Organizations (NGOs) such as Sea Sherped and Greenpeace, which play a role in antiwhaling resistance.

Opposition or rejection of a norm proves that the beliefs or actions of an actor are considered unacceptable by other actors, even though the norm does not have to be official or written. This refusal will bring criticism from other actors, in the case of international norms, criticism can come from anywhere including NGOs, countries and international organizations. Australia is one of the countries that is vocal against Japan's scientific whaling disapproval, in 2010, Australia filed a lawsuit against the ICJ regarding JARPA II and was only granted by the IWC in 2014 by terminating Japan's JARPA II in Antarctica. Japan, which was under pressure from anti-whaling groups, decided to withdraw on December 28, 2018, which was also the culmination of Japan's decision to maintain whaling.

\section{Theoretical Framework}

In this study the author uses a framework of thought in the form of the concept of Legitimacy of International Norms and National Interests. The concept of legitimacy is a normative belief for an actor that can be used to emphasize a rule, law, and an institution that must be obeyed. Legitimate international norms can influence the behavior of a country, but legitimacy can also be used as a reason to comply with or reject a norm. In relation to state behavior, Beetham also describes a chart that connects the social context that contains sources of legitimacy on state norms and behavior.

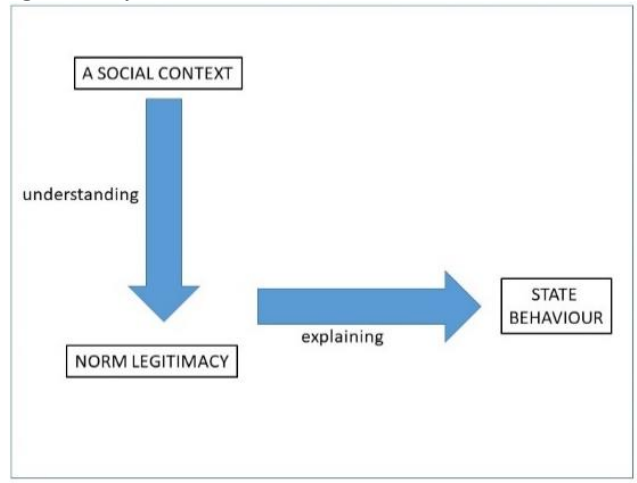

Fig. 1. Concept of Legitimacy of International Norms and National Interests 
The chart above explains that the legitimacy of a norm can be understood by the state by looking at the social context in its domestic territory and supported by sources of legitimacy. The incompatibility that occurs between the social context and international norms can be understood as an illegitimate norm and can affect state behavior in responding to these international norms. International norms can be adopted or rejected by a country depending on the sources of legitimacy that support it or also referred to as a state response to international norms. Among them, there are three sources of legitimacy, namely express consent, ideational consistency, and relationships between groups or groups.

In this concept, it will explain how Japan understands the legitimacy of international norms through the social context facing Japan or originating from within Japan. So that Japan can use the social context to determine its behavior towards these norms. This can be understood by Japan as the stage of this country in adopting an international norm [5].

While in the theory of national interests, Joseph Frankel explained that a stable national interest brings good conditions for a country, Frankel also explained that national interests are all forms of needs related to the main goals of a country in the form of an independent foreign policy [6]. The concept of national interest seems to provide a norm for the state to achieve all its goals without caring and looking at other countries as long as their interests are achieved.

In this theory, the author uses the classification of national interests according to Thomas W. Robinson and Rosenau, namely the classification of primary interests. In this classification, the interests of the state cannot be disturbed by any state even in terms of compromise. It includes defending physical, political, and cultural identities against possible interference from other countries. This concept will help explain that Japan's national interest is whaling as a means of fulfilling food needs and preserving the whaling culture that Japan has practiced for thousands of years. These two things became Japan's benchmarks in maintaining whaling.

\section{Result and Discussion}

Whale hunting has occurred since thousands of years ago, this activity is carried out because all parts of the whale's body can be utilized such as meat, skin, fat, and internal organs of whales as a source of protein, vitamins, fats and minerals. Countries that do whaling include the Netherlands, England, the United States, Norway and especially Japan. Japan is a country that has a long history of whaling. Historical records reveal that the Japanese have been hunting whales since the 7th century. Starting from the Asuka-Yamato period when Japan was still in the form of an empire. In the oldest recorded history book in Japan, the Kojiki, it is stated that whale meat is included in the Japanese emperor's snack list (MAFF Japan). The development of whaling in Japan had a direct impact on Japanese whaling culture and traditions such as gyoshoku-bunka (whale-eating culture), dances, rituals and in particular also related to the spread of Buddhism and Shinto in Japan.

Since the issue of whaling was discussed in an international forum in 1931, this issue has rapidly received the attention of many parties. Including the United Nations which later raised this issue in the UNCHE forum. Initially in 1930, the Bureau of International Whaling Statistics was formed to monitor the activities of the whaling industry, such as the number of whales caught compared to the number of whale populations [7]. A year later, a regulatory agreement on whaling was signed, namely the International Convention of the Regulation of Whaling (ICRW), which was deemed ineffective in regulating the whaling industry. After the ICRW was convened, in 1946 the second convention was held, 14 of the 22 members proposed to establish an international regime that fully regulates the restrictions on whaling in accordance with the ICRW vision and mission, then agreed to establish the International Whaling Commission (IWC) [7]. In 1951, Japan became a 
member of the IWC. The reason for joining the government and whaling industry players in Japan is that they feel they will benefit from joining the whaling regime. Another reason is that Japanese society experienced a crisis after World War II. Joining the IWC is also used to restore Japan's reputation internationally and to show the international community that Japan can also be a trusted partner that meets international standards.

According to ICRW, the purpose of establishing IWC is to provide facilitators, especially in international whale conservation that has standards and complies with regulations, so that the whale industry can develop well. Entering the late 60 's, the IWC experienced a paradigm shift from the previous regime of supporting a sustainable whaling industry to a very conservative institution that even opposed all forms of the whaling industry and was followed by the development of international norms against whaling which in this case was not profitable for Japan. In 1972, UNCHE (United Nations Conference on the Human Environment) became the beginning to accelerate the IWC paradigm change, which then 10 years later appeared the 1982 moratorium. The 1982 moratorium showed clearly that the IWC paradigm experienced a shift as an international whale conservation institution. The implementation of the moratorium is motivated by the development of anti-whaling norms in the international community. The existence of this norm has been successfully introduced by norm entrepreneurs, namely NGOs, countries and international organizations. And the massive campaign carried out by environmental groups against this norm and the IWC as a stage in delivering this norm is considered successful. In addition, norm-promoting countries such as the US, Australia, France, UK, New Zealand and Germany have succeeded in forming an anti-whaling coalition which is considered successful in determining policy at the IWC. However, Japan also failed in this effort against Japan, which was actually resistant to whaling even with the sanctions imposed by the US.

The 1982 moratorium became an obstacle for Japan to continue its whaling. However, Japan's persistence to continue these activities did not stop with the imposition of a moratorium. Japan uses a scientific whaling program to continue their whaling activities, this method is considered legal because it is stated in Article VIII paragraph 1 of the International Convention for the Regulation of Whaling (ICRW), in which ICRW allows a country to hunt for research purposes. To support this research, Japan established a special research body for cetaceans and other species including whales, namely the Institute of Cetacean Research (ICR). The ICR is an independent official body that is part of shaping the scientific whaling policy of the Government of Japan. This closeness is also established through the Ministry of Agriculture, Forestries and Fishries (MAFF) of the Government of Japan, as a government institution that has links with these activities. Meanwhile, in terms of promotion of whale meat, the Japanese government cooperates with a special corporation, namely Kyodo Senpaku, which is engaged in meat marketing, in this case whale meat. Japan proposed the first whale research program in 1987, namely the Japanese Antarctic Research Program (JARPA) which was then implemented in 1988-2005, the Japanese Research Whaling Program in the North Pacific (JARPN) was carried out in 1994-1999, JARPN II was carried out in 2000-2005. 2016, and JARPA II conducted from 2005-2014, as well as the New Scientific Whale Research Program in the Antarctic Ocean (NEWREP-A) which took place in 2015-2016 after the ICJ terminated the previous Japanese whale research program. In 2017, Japan also proposed the New Scientific Whale Research Program in the western North Pacific or NEWREP-NP.

The international anti-whaling norms aim to prohibit all forms of whaling practices, especially those carried out in a lethal or lethal manner. This norm is directly related to the Japanese view on Japanese whaling practice, whether or not this norm is adopted depends on the strong or not the sources of legitimacy, categorized by Isao Miyaoka. These sources include expressed consent, ideational consistency, and inter-group relations. There are at 
least three factors in Japan's rejection of international norms. First, based on the sources of legitimacy of these norms, Isao Miyaoka categorizes them into three.

In this first source of legitimacy, there are two arguments that can answer this first source of legitimacy. First, the success of the 1982 Moratorium is one of the representations of the majority vote carried out by anti-whaling countries and NGOs by paying votes to nonwhaling groups and countries to follow or vote on any proposals and resolutions on antiwhaling policies. However, the IWC as an official institution did not issue a resolution against the Japanese research program [5]. Second, the IWC is getting weaker in giving and making decisions, especially in Japanese research programs with the use of the word chosen in each resolution that has no binding meaning and is politically weak, such as the 1989 resolution that is considered more in favor of the Japanese government than previous resolutions on the same topic., the use of the word in the resolution "Recommends the Government of Japan" is a weaker expression than "Invites the Government of Japan to reconsider its research program". Coupled with the failure of this resolution, because it did not reach a majority vote and was smaller than before; 13 agreed, 6 rejected and 8 abstained.

The second source of legitimacy is the low iedational consistency. Japan uses a special exception to whaling, namely scientific whaling which allows member countries to conduct scientific whaling, the legality of which is stated in ICRW Article VIII. The regulation in Article VIII clearly distinguishes between commercial hunting and hunting for research purposes. On the other hand, Japan protested against the permitting of Aboriginal whaling programs, while Japan, which is also rooted in culture, was not granted permission. The striking difference between the anti-whaling norms adopted by anti-whaling groups and the resolutions aimed at Japan with the articles in ICRW and the exception to aboriginal whaling proves that this norm is illegitimate to be adopted, inconsistent and one-sided. Meanwhile, from a scientific point of view, the determination of the 1982 moratorium is considered unfounded from a scientific point of view, the lack of certainty regarding whale stocks in the oceans which makes pro-whaling groups doubt the basis for determining this moratorium. The last source of legitimacy is weak inter-group relations. The relationship between the promoter country and the target country greatly affects the legitimacy of an international norm. In this case, the United States as the promoter and Japan as the target country have established relations since post-World War II, even though the two countries are considered the strongest post-World War II alliance. In the issue of animal welfare, especially whaling, the United States is a country that promotes anti-whaling norms. The United States should be able to get Japan to adopt this anti-whaling norm and Japan can also easily adopt this norm as a form of conformity on the part of the alliance. The failure of the US as a promoter of this norm was caused by the conflict between the US and Japan. It is known that the promoter in this norm is not only the US, behind it involved NGOs that support and influence Japan, including Greenpeace, Sea Sherped, and Wildlife link. If the relationship between US promoters and environmental NGOs is not in a situation that will worsen Japan's understanding of this norm, it is likely that in the not too distant future Japan will be able to adopt this anti-whaling norm.

The second factor in Japan's rejection of this norm was that the IWC as a single regime governing the papacy was considered powerless or weak in carrying out its roles and functions. In this regard, the compliance of ones towards a regime cannot be guaranteed [8]. In this regard, the compliance of ones towards a regime cannot be guaranteed Finnermore and Sikkink explain that an effective norm can be adopted massively if there is a strong sanctions and enforcement mechanism [9]. In addition, the weakness of the IWC is also proven by the use of the word in every resolution that comes out which tends to have no binding force in the prohibition of Japanese whaling, both commercial and scientific whaling. The weakness of the IWC makes the US have to carry out its role as an influential 
country in the IWC, it is noted that the US has imposed three sanctions on Japan. The pope through the US Department of Commerce in every international trade forum. Third, the boycott of the environmental conference by President Clinton which was held in Tokyo, Japan in 2000. These sanctions also did not make Japan adopt this norm so that the US also failed to promote the norm.

The third factor that Japan rejects this norm is because of their domestic culture, there is no conformity between international norms and the culture of Japanese society even though this is an important factor in determining attitudes to adopt or reject. Japan itself has practiced the culture of consuming whale meat since thousands of years ago, this culture is known as gyoshoku-bunka (whale-eating culture) [10]. In the Shinto religious belief, Japanese people will pray to express gratitude for the gift of whale meat and pray for the spirit of the whale that has been hunted. Kalland also equates that the culture of consuming whale meat in Japan can be compared to the culture of not consuming beef in Hinduism and not consuming pork in Islam [11]. Japan also believes that whales are manifestations of the god Ebisu, the god who brings wealth from the sea.

After years of joining the IWC, in December 2018 the Government of Japan announced its withdrawal from the IWC and confirmed that it would continue the commercial whaling program that was blocked by the IWC through the 1982 Moratorium. Since the moratorium was imposed, Japan has made efforts to lift the moratorium. But the proposal is often rejected by anti-whaling groups. Before declaring their withdrawal from the IWC, at the 67 th IWC meeting in Florianopolis, Brazil, the Japanese delegation presented the proposal again after making revisions. In the proposal, the Japanese government set catch quotas for certain whale species and the category is not endangered. The results of the voting that were not in favor of Japan were from 40 countries that voted, 27 of them rejected the proposal. This result means to bring good news to anti-whaling countries and environmental NGOs. Through the Deputy Minister of Fisheries of Japan, Masaaki Tanai said he would evaluate whether Japan would continue to remain in the IWC or withdraw [12].

After Japan's withdrawal from the IWC in December 2018, Japan resumed commercial whaling in July 2019. With Japan's withdrawal from the IWC, Japan was prohibited from carrying out commercial whaling activities in the Antarctic region and could only hunt whales in Japan's Exclusive Economic Zone (EEZ), according to with the rules of international law (UNCLOS). Although not a member of the IWC, the Japanese government still has to report the number of whales caught in accordance with IWC rules, this is intended to maintain the number of whale populations in the ocean. Japan's withdrawal from the IWC because of the country's main interest in the issue of whaling, this is one of the reasons why Japan chose to leave the International Whaling Commission. In addition, Japan also demands the IWC regarding aboriginal subsistence whaling to be given the same rights to their communities in coastal areas of Japan, which also have a special tradition of whaling. This community has traditionally depended on small-type coastal whaling and they must be given a special quota to hunt 50 minke whales per year, Japan also states that this type of whale is safe to hunt [2].

Whaling activities carried out by Japan are certainly not easy to do, in practice Japan is under pressure from various parties who are generally referred to as anti-whaling groups. The fact is that the issue of whaling in Japan is not considered an environmental problem and in Japan itself there are only a small group of environmental NGOs that express disapproval of Japanese whaling activities including Greenpeace Japan, the Japan Wildlife Conservation Society, and the Ikura \& Akira Action Network [13]. Almost all forms of anti-whaling activity in Japan are dominated by non-Japanese activists. Anti-whaling groups have made various efforts to stop this Japanese whaling activity. One of the ways to do this is by always attending environmental conferences, whether organized by the United 
Nations or the IWC, in which NGO delegates asked countries to stop consuming whale meat, especially Japan, which has a tradition of consuming whale meat. Apart from that, in other forms, the activists also disclosed the facts on the issue of Japanese whaling. Greenpeace Japan activists, managed to find the fact that the whale meat was diverted by being sent to officials related to whaling activities and being sent to high-end restaurants in Japan illegally through Kyodo Senpaku [14].

The Japanese government's response was to conduct an investigation related to the allegations by Greenpeace Japan and then order the Japanese national police to arrest the activists involved. The Japanese government used the reason for arresting the crime of theft. The second response was to threaten to revoke the legality of Greenpeace Japan so that they could no longer protest. Another action carried out by environmental activists was the blockade of Japanese research ships. The blockade was carried out by Sea Sherped and Greenpeace, the two NGOs blocked the ICR Nisshin-maru ship, the blockade occurred in the Antarctic waters. This was then responded by the ICR, through its official website. On its website, the ICR said that the actions taken by Greenpeace and Sea Sherped were too aggressive. After the blockade action, the Government of Japan proposed by making rules so that these actions can be avoided which were included in the proposal at the regular IWC meeting, but the proposal was strongly rejected by the US and ended in failure [15].

\subsection{Japan's Social Context and the legitimacy of international anti-whaling norms}

According to David Beetham's chart, the relationship between the influences of social context on the legitimacy of norms is also related to state behavior. Weak sources of legitimacy for anti-whaling norms, whale eating culture, and weak sanctions make these three social contexts that affect the legitimacy of anti-whaling norms and their implications for Japan's behavior towards these norms. The chart below explains the social context according to David Beetham:

\begin{tabular}{|c|c|c|c|c|}
\hline $\begin{array}{l}\text { Japanese Social } \\
\text { Context: } \\
\text { a. Weak sources } \\
\text { of norm } \\
\text { legitimacy } \\
\text { b. Japanese } \\
\text { domestic culture } \\
\text { c. Weak IWC } \\
\text { sanctions for } \\
\text { violation of } \\
\text { norms }\end{array}$ & Understanding & $\begin{array}{c}\text { Legitimacy } \\
\text { of Anti- } \\
\text { Whaling } \\
\text { Norms }\end{array}$ & plaining & $\begin{array}{l}\text { Japanese Behavior } \\
\text { a. Not adopting } \\
\text { anti-whaling } \\
\text { norms } \\
\text { b. Withdraw from } \\
\text { IWC membership }\end{array}$ \\
\hline
\end{tabular}

Fig. 2. Legitimacy of anti-whaling

In the chart above, it is explained that in understanding the legitimacy of anti-whaling norms through the social context, it greatly influences views on anti-whaling norms such as whether they are legitimate or not to be adopted. In fact, Japan views that the level of legitimacy of the norm is so low that Japan's behavior towards the norm does not change or does not adopt it and withdraws from the IWC as an implementation of the rejection of the anti-whaling norm. 


\section{Conclusion}

The issue of anti-whaling has developed and is recognized as an international norm after many countries have become promoters and their views on the environment have changed. The United States, Australia and the United Kingdom are the three main promoters of this anti-whaling norm. On the other hand, there are also countries that were previously involved in the whaling industry but still continue or are known as pro-whaling countries. Those pro-whaling countries expect commercial whaling to be allowed again, including Norway, Iceland, and especially Japan. Japan has been doing whaling since the imperial era, this is evidenced by the food menu, namely satisfied meat that was always served to the emperor in the 7th century. Japan has experienced rapid development in whaling activities starting from the hunting technology used, the species of whale being hunted, the hunting area or waters, to changes in the whaling community. These activities developed into traditions in Japanese society such as dances, religious rituals, and the tradition of eating whale meat or gyoshoku-bunka.

The 1982 moratorium put an end to all whaling activities and was the beginning that this norm was successfully enforced at the IWC. However, the enactment of the 1982 moratorium did not stop Japan from carrying out whaling activities, through its Government, Japan issued a whaling program with the aim of research or Scientific Whaling. Carrying out a research program indicates that Japan is not adopting this norm and instead has declared its withdrawal from the IWC in 2018. So that the authors get results regarding the three reasons why Japan rejects this norm. First, Japan views that the anti-whaling norm is a very illegitimate norm to be adopted. Based on three sources of norm legitimacy, namely expressed consent, ideational consistency and inter-group relations, namely the state, which can explain that the relationship between the promoter country and the target country is very low. Second, the weakness of IWC sanctions as an international regime against norm violators, including the US as a hegemonic country as well as Japan's largest alliance. Third, there is no congruence between Japanese domestic culture and this anti-whaling norm. Japan adheres to the norm of whales that deserve to be eaten, through its culture of gyoshoku-bunka (whale-eating culture). Not only on the culture of pope consumption in society, but also related to the spread of Shinto and Buddhist teachings. The climax was when Japan decided to withdraw from the IWC on December 26, 2018, this was done because in the era of President Donald Trump there was not much attention and relations on this issue were very low.

Japan, which explicitly and clearly did not adopt this norm, did so by understanding the sources of legitimacy and then taking a stance as an implementation of the rejection of international anti-whaling norms. In relation to the theory of legitimacy of international norms by Isao Miyaoka and David Beetham used in this study, Japan chose not to adopt these international norms. Meanwhile, in the theory of national interest by Thomas W. Robinson and Rosenau. In relation to national interests, Japan chose to withdraw from the IWC as a form of rejection and firm stance from Japan. Since 1982 Japan has complied with the rules as a member of the IWC and has not conducted commercial whaling and has only complied with Article VIII on Scientific Whaling.

\section{References}

1. C. Juma, The Future Of The International Whaling Commission Strengthening Ocean Diplomacy Special Advisor International Whaling Commission Report Prepared for the International Whaling Commission, (2008).

2. K. Hirata, J. Int. Wildl. Law Policy 8, 129 (2005). 
3. Nippon.com, Whale Meat No Longer a Major Protein Source in Japan, (2019).

4. D. Goodman, Evolution of the IWC Scientific Committee, 71 (2017).

5. I. Miyaoka, Legitimacy in International Society (Palgrave Macmillan UK, London, 2004).

6. J. Frankel, National Interest (Palgrave Macmillan UK, London, 1970).

7. WWF, The History of Whaling and the International Whaling Commission (IWC), (2005).

8. S. Sudiar. Rezim Kerjasama Sosek Malindo Kaltim-Sabah: Mengukur Derajat Compliance Partisipan Perjanjian. Jurnal Hubungan Internasional, 3, 33-43. (2012).

9. M. Finnemore and K. Sikkink, Int. Organ. 52, 887 (1998).

10. K. Sumi, The Whale War between Japan and the United States: Problems and Prospects,(2020).

11. A. Kalland, Unveiling the Whale: Discourses on Whales and Whaling (Environmental Anthropology and Ethnobiology) (New York: Berghan Book, 2009).

12. The Guardian, Australia urges Japan to remain in IWC after its bid to lift whaling ban rejected, (2018).

13. M. Danaher, Pacifica Rev. Peace, Secur. Glob. Chang. 14, 105 (2002).

14. Greenpeace USA, Greenpeace investigation: Japan's stolen whale meat scandal, (2008).

15. T. Kojima, The Japanese Research Whaling, (1993). 